\title{
Habits to save our habitat: Using the psychology of habits to promote sustainability
}

\author{
Asaf Mazar*, Geoffrey Tomaino*, Ziv Carmon, \& Wendy Wood
}

\begin{abstract}
Public awareness and concern about climate and environmental issues have grown dramatically in the United States and around the world. Yet this shift in attitudes has not been accompanied by similar increases in eco-friendly behaviors. We propose that this attitude-behavior gap is partly driven by the difficulty of changing unsustainable habits. Governments and businesses can reduce this gap through interventions that draw on insights from research into the psychology of habits and behavioral economics. First, they can reduce or add friction, making it easier for people to engage in eco-friendly actions and making it harder to continue environmentally damaging practices. Second, they can set up action cues-prompts that trigger pro-environment actions - and deliver these cues where and when they will have the biggest impact. Finally, they can provide psychologically informed incentives and disincentives that steer people toward environmentally beneficial actions. We also describe how even initially unpopular policies can become accepted through habitual repetition. In these ways, habit psychology represents a promising addition to the policymaker's toolbox.
\end{abstract}

Mazar, A., Tomaino, G., Carmon, Z., \& Wood, W. (2021). Habits to save our habitat: Using the psychology of habits to promote sustainability. Behavioral Science \& Policy, 7(2), XX-XX.

*Both authors contributed equally to this manuscript. 
The 2006 film An Inconvenient Truth made an eloquent and impassioned call for immediate climate action, combining heart-wrenching storytelling with statistics to highlight the grave state of the environment. ${ }^{1}$ It earned two Academy Awards and became one of the highest grossing documentaries of all time. ${ }^{2}$ In 2007, the film's creator, Al Gore, even received the Nobel Peace Prize. ${ }^{3}$ This recognition is likely due to the dramatic effect the movie had on viewers' attitudes. When polled in 2007, $66 \%$ of respondents indicated that the film had changed their attitudes toward global warming. ${ }^{4}$ In another survey, filmgoers reported that it had strengthened their intentions to engage in pro-environment behaviors, such as contacting their senator or contributing to an environmental organization. ${ }^{5}$

Since then, concern about climate change has continued to grow globally. In a 2018 survey across 26 nations, climate change was ranked the most important global threat, above issues such as terrorism, nuclear weapons, or economic concerns. ${ }^{6}$ About $67 \%$ of survey respondents rated climate change a major threat-a substantial increase from the $56 \%$ of respondents who did so just five years earlier. Clearly, people in both the developed and the developing world recognize climate change as a crucial priority.

Yet changed attitudes have not been accompanied by changed behavior. A recent synthesis of 196 studies and polls found that eco-friendly attitudes and intentions were only modestly associated with eco-friendly behavior. ${ }^{7}$ And back in 2007, when researchers followed up a month later with the filmgoers who had expressed intentions to take action after seeing Gore's film, adherence to those plans was dismal. For example, none had contacted their senator, and only one had contributed to an environmental organization. ${ }^{5}$ Another study showed that even when the film prompted immediate action, the effect faded quickly, completely dissipating within two months of the movie's release. ${ }^{8}$

Interventions that change minds often do not change behaviors. It seems that people fail to act to protect the environment not because they lack concern but rather despite their concern, often because they keep reverting to old, habitual behaviors. In this article, we suggest solutions to such inaction that are based on research into habit psychology and behavioral economics, which examine the psychological factors that cause people to stray from rational behavior. We show how policies and technological tools can leverage proven behavior-change principles to break environmentally unsustainable habits and form new, eco-friendly ones in their place.

New approaches are needed because public policies too often fail to address the gap between attitude and behavior. ${ }^{9}$ The U.S. government spends approximately $\$ 1.5$ 
billion annually on public relations and advertising, with much of this money going toward public awareness campaigns aimed at changing attitudes. ${ }^{10}$ In the environmental policy sphere, such information, much like Gore's film, has been found to have only minimal effects on behaviors such as household energy use. ${ }^{11}$ And yet many governments continue to produce attitude-change campaigns rather than turning to more forceful, top-down approaches such as legislation, perhaps because of the broad public acceptance of information-based approaches that maintain individual freedom of choice. ${ }^{12,13}$

\section{Why Altering Habits Is Critical to Environmental Protection}

An understanding of habits is key to understanding why people do not align their behavior with pro-environmental attitudes. A habit is a tendency to act automatically that reflects a mental association between a situation and a response. People learn these associations by repeating a behavior in a given situation. With repetition, reward-sensitive brain regions come to associate the situation with actions that worked in the past. Eventually, just being in a familiar situation brings the habitual action to mind. ${ }^{14}$ For example, when you get into a car (a familiar situation), you might put on a seat belt automatically (a habitual action). Once you have formed a seat belt habit, you do not need to consciously decide to buckle up every time you enter a car - the action comes to mind without much thought. ${ }^{15}$ Thus, habits reflect mental shortcuts that automate frequently performed actions so that people can repeat them without deliberation.

People's everyday activities generate a sizable proportion of anthropogenic (humanactivity-related) greenhouse gas emissions. Many people consume foods rich in animal products, which typically require intensive use of land, fossil fuels, water, and chemicals to produce and distribute; travel by air and automobile; and use excessive energy at home. ${ }^{16}$ These activities are largely habitual: People repeatedly eat familiar foods at set times, ${ }^{17}$ travel similar routes at similar times of day using the same travel modes, ${ }^{18,19}$ and mindlessly consume energy while at home. ${ }^{20}$

Interventions that counter undesirable habits and simultaneously foster the formation of new habits are key to effective change. Although people can be convinced to act in new ways for short periods, they tend to revert to old habits when stressed, tired, or distracted. ${ }^{21,22}$ That is, they fall back into practiced actions rather than maintaining behaviors that are more consistent with new attitudes or social norms. ${ }^{23,24}$ For example, in one study, households were given feedback that compared their energy consumption with their neighbors' ${ }^{25}$ The intervention initially reduced households' energy use for a few days, with consumption quickly rebounding to baseline as households reverted to their habitual consumption patterns. The energy use decrease 
was maintained only with repeated feedback. These results show how strong habits can act as barriers to otherwise successful interventions. ${ }^{26}$

Fortunately, policies can harness habits to power environmentally sustainable choices. Once habits are created, they persist even when people are not thinking about the environmental impact of their behavior. For instance, once people form the habit of regularly commuting by bike, they stick with cycling even when trips become complex and involve multiple stops. ${ }^{27}$ Demonstrating the role of habits in maintaining both sustainable and unsustainable behaviors, habitual drivers and bicyclists seem to be bound to their usual travel mode and show little interest in other options. $^{28,29}$

In our view, changing environmental behavior for the long term requires structural changes: creating circumstances that encourage the repetition of desirable actions and discourage the habitual performance of undesired ones. These changes can take the form of setting new defaults, which determine what happens unless people actively select a different option. At a Danish academic conference in 2019, for instance, some attendees received a registration form in which the default meal choice included meat. Most people prefer meat, so it was not surprising that only $10 \%$ of conference goers asked to switch to the vegetarian option. However, when other attendees were given a registration form with a vegetarian meal default, $80 \%$ of them stuck with that choice. ${ }^{30}$

The impact of defaults can extend beyond immediate choices. A similar study conducted in Swedish restaurants found that placing a vegetarian meal at the top of the menu increased the number of vegetarian meals chosen, an effect that largely persisted months after the original menu order was restored. ${ }^{31}$ The order of the menu provided what behavioral economists call a nudge: a change that encourages a certain behavior without limiting individual choice. The restaurant's nudge may have helped form habits that persisted even after the nudge was removed. The success of such interventions has inspired structural changes such as those advocated by the organization DefaultVeg, which successfully convinced several U.K. food providers to switch to vegetarian-default menus. ${ }^{32}$

The resetting of menu defaults provides a simple example of how structuring situations to guide eco-friendly habits can lead to dramatic behavior changes without shifting attitudes or requiring monetary incentives. There are many more. 


\section{How to Help People Create New, Better Habits}

Research points to three broad principles for designing interventions that promote repetition of environmentally desirable behaviors: modifying friction, adding or removing action cues, and leveraging psychologically informed incentives (see Table 1). As we show next, these principles can guide structural changes so that individuals form desirable habits and break existing undesirable ones.

\section{[Table 1 Here]}

\section{Principle 1: Modify Friction}

The first principle involves modulating friction - the perceived difficulty of performing a behavior. Interventions that modify friction alter situations to make desirable behaviors seem easier, undesirable behaviors seem more difficult, or both. Even minor increases or decreases in friction — ones that would not initially be expected to have much impact on behavior - can induce change. Although it is a truism that people choose the path of least resistance, friction interventions are rarely put to good use.

As the earlier seat belt example suggests, repetition reduces friction. When a behavior that is difficult is repeated so much that it becomes a habit, repetition can make the once-difficult action feel familiar, safe, and easy. ${ }^{33}$ The power of habits must be taken into account when trying to use friction to change behavior.

An instructive example comes from Calgary, Canada, where residents were encouraged to grasscycle: that is, let grass clippings naturally decompose on the lawn instead of collecting and disposing of them after mowing. ${ }^{34}$ Adoption rates for grasscycling were lower than expected. Even though grasscycling objectively requires less effort, the deviation from routine may have made it feel difficult.

Reduce Friction to Encourage Eco-Friendly Behavior. Even slightly reducing the friction on desired behaviors can go a long way toward encouraging new, better habits. In one study, recycling uptake in an office setting doubled after recycling bins were placed right next to trash bins instead of a short distance — only 4 meters (roughly 13 feet) - away. ${ }^{35}$ In another study, placing a personal recycling bin next to each desk in an office decreased the amount of paper waste sent to a landfill. ${ }^{36}$ And when recycling receptacles on a university campus were moved inside classrooms, the rate of aluminum can recycling doubled. ${ }^{37}$

The experiment in which a personal recycling bin was placed at each desk is noteworthy because a similar recycling bin was already sitting at the center of the 
office space. ${ }^{36}$ The intervention simply removed the need to get up and walk a few steps to recycle, illustrating the strength of spatial distance as a form of friction. The office workers had maintained their elevated recycling rates when revisited two months postintervention, suggesting that they had formed recycling habits.

Interventions that reduce friction can be used to encourage travelers to use modes of transportation that reduce pollution and save energy. For example, transit systems can provide travelers with real-time service information about their wait times, mitigating the aversive uncertainty of irregular bus and train schedules. ${ }^{38}$ Econometric studies indicate that large U.S. cities that instituted real-time service information increased bus and train ridership by $2 \%{ }^{39}$

Interventions can also reduce friction by simplifying behavior, such as by decreasing the number of steps or the amount of decisionmaking required. Strategies that simplify behavior can also hasten habit formation, because simple behaviors consolidate into habits faster than more complex ones do. ${ }^{40,41}$

By making multimode travel simple and frictionless, policymakers can build a clear runway for pro-environment transit habits. The use of smartphones for navigation, for example, is associated with greater use of multiple modes of transportation. ${ }^{42}$ Mobility apps such as Google Maps or Apple Maps can promote sustainable transportation habits by making it easier to combine bus and train rides. Individuals using these apps might make decisions that are even better for the environment if low-emission modes such as walking and biking are set as defaults, reducing friction on those choices.

Transit apps are evolving in a friction-reducing direction, becoming MaaS (mobilityas-a-service) applications that integrate multiple transportation service providers. MaaS apps have the potential to facilitate eco-friendly transit behaviors by reducing search and time costs across a variety of transit modes. ${ }^{43}$ The potential of multimode travel is evident in Germany, where regional transit organizations coordinate public transit - for example, by integrating bus and rail subscriptions and by building cycling facilities next to transit stations. ${ }^{44}$

The design of the built environment can also harness friction by making some transportation modes easier to use. An analysis of 13 U.S. metropolitan areas showed that residents are more likely to cycle when provided with bike lanes protected from motor traffic. ${ }^{45}$ Similarly, in residential neighborhoods with wellconnected sidewalks and access to shops, people walk more and drive less. ${ }^{46}$ The practical utility of bike lanes is further underscored by their extremely low price: 
The city of Portland, Oregon, estimated that the cost of just one mile of freeway can fund 240 miles of the city's extensive bike-friendly boulevards. ${ }^{47}$ Furthermore, such structural changes exert broad effects, not limited to those who are already inclined to walk and cycle. Even residents who prefer driving end up walking more when they live in walkable neighborhoods. ${ }^{48}$

Increase Friction to Discourage Undesirable Actions. Just as reducing friction promotes desirable behaviors, increasing friction can decrease undesirable ones. One effective way of increasing friction is to impose time delays. Even brief delays can cause notable shifts in behavior. In one study, a 16-second delay in closing elevator doors at a university reduced elevator trips, cutting energy use by a third. ${ }^{49}$ In comparison, signs posted to encourage people to save energy by taking the stairs had no effect. Remarkably, the energy savings continued even after the delay was removed, suggesting that people had formed long-term stair-climbing habits while the delay was in effect.

Even imperceptible structural changes that slightly increase friction can have farreaching consequences. For example, some German households were offered a standard energy contract - that is, one using power generated from conventional sources - as their default choice but were given the option to switch to a green contract. ${ }^{50}$ Fewer than $8 \%$ chose the green alternative. When other households were offered the green energy contract as the default choice, almost $70 \%$ adopted the green option - a tenfold increase.

Similarly, defaults can be applied to habitual behaviors that determine everyday energy use. ${ }^{51}$ For instance, in a study conducted in a virtual office environment, participants tended to stick with the default light setting, so setting the default to natural light resulted in energy savings. ${ }^{52}$

Another study examined the effect removing trays had on food waste in a university dining hall. ${ }^{53}$ Just as a slow elevator door added friction to the habit of taking the elevator, removing trays added friction to patrons' tendency to pile on excess food, reducing food waste by of approximately $18 \%$.

In yet another example, researchers partnered with a luxury hotel chain to reduce guests' water use. The hotels installed dual showerheads in their bathrooms, with one of the heads, the full-pressure one, turned off as a default. After this change, fewer than $20 \%$ of the guests used the full-pressure showerhead. ${ }^{54}$ 
To promote environmental sustainability, urban planners should increase friction on environmentally unsound options while reducing friction on desirable choices. Traffic calming, for example, involves designing streets to reduce traffic speed, using such measures as speed bumps. Although traffic-calming measures were created with safety in mind, they also reduce car use through the friction that they impose on driving. Living streets (woonerf) originated in the Netherlands as zones in which pedestrians and cyclists took precedence over cars. The Tempo-30 zones that are now common in European cities limit traffic speed to 30 kilometers per hour (approximately 19 miles per hour). In addition, German city centers often include one-way streets, car-free zones, and other features intentionally introduced to discourage car use. ${ }^{44}$ Such features - having to drive slowly, via circuitous routes, while sharing the road with pedestrians and cyclists - can disrupt the habit of driving by making car use effortful and deliberate. Indeed, traffic-calming measures reduce congestion while increasing safety for drivers, cyclists, and pedestrians. ${ }^{55}$

\section{Principle 2: Leverage Action Cues}

Another approach to increasing eco-friendly behavior is to add, remove, or replace action cues. Examples of such interventions include providing recycling containers, which signal by their presence ways to dispose of waste; giving households immediate, concrete feedback on energy use; and fitting showers with visible clocks to reduce water waste.

Recurring cues are especially important for habit formation. As habits form, cues become associated in memory with an action, eventually causing the perception of the cue to automatically trigger the action. ${ }^{56}$ Similar to friction, cues can be leveraged both to encourage the formation of desirable habits and to discourage undesirable ones.

To be most effective, action cues should be specific and prompt straightforward, concrete actions. Simple, unambiguous cues may be especially suitable for reinforcing the automatic cue-response associations that characterize habits. ${ }^{56}$ For example, signs are more effective at getting people to recycle (and to do so correctly) when they use visuals rather than words ${ }^{57}$ and when verbal instructions are limited to a few words in large, easy-to-read fonts. ${ }^{58}$ Another simple cue for waste disposal is what other people are doing, as indicated by the amount of litter already in a setting. People are less likely to litter in a clean setting than in one that is strewn with trash. ${ }^{59}$

Cues are also most powerful at the point of action. If presented too early, they might fade from memory by the time they are needed; if presented too late, they might arrive after people have already initiated old, undesirable habits. In one instance, a recycling initiative in a university dining hall foundered when students were given 
recycling instructions as they entered the cafeteria, long before they had to dispose of their dishes. ${ }^{58}$ Once simple, actionable signs were placed on the dining hall trash cans where students disposed of their waste, recycling levels tripled, and food contamination of recycled material decreased. Messages that highlight a building's LEED certification - verifying that the building complies with the green building requirements of the Leadership in Energy and Environmental Design program - can similarly serve as cues to increase recycling and to reduce energy use when people are in such buildings. ${ }^{60}$

Recycling at Work, a 2014 research project commissioned by Keep America Beautiful, provides another creative example of visual cues. ${ }^{61}$ In most offices, a typical waste disposal station has equal-size bins for waste and recycling (and sometimes smaller sizes for the latter). In place of the same-size bins, this intervention provided office workers with large recycling bins paired with much smaller trash bins (see a similar design in Figure 1). The bin sizes provided a clear, simple visual cue that encouraged recycling right at the location where workers had habitually tossed waste in the trash bin. Indeed, this minor adjustment reduced the amount of recycled materials wrongly discarded in the trash bin by $25 \%$.

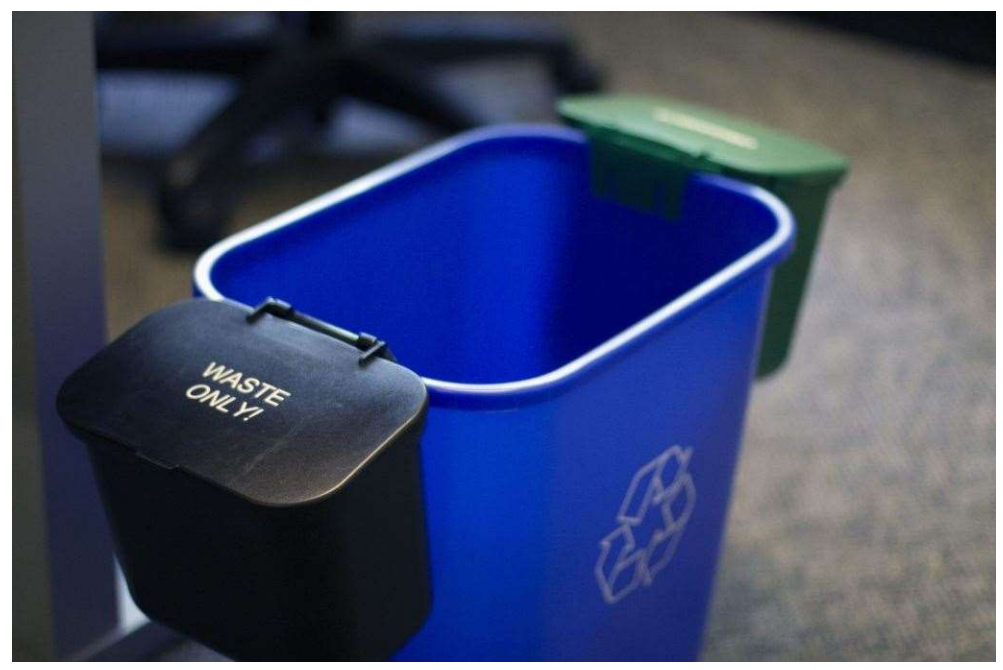

Figure 1. A recycling-promoting waste bin configuration consisting of a large recycling bin beside a smaller trash bin

Note. This multiple-disposal-bin configuration provides a salient visual cue for recycling while minimizing the cue for waste bin use. When office workers in several locations across the United States were given bins in a similar configuration, recycling increased by $30 \%$ compared with locations using equal-sized bins. Photo credit: Bellevue College Office of Sustainability. Reprinted with permission. 


\section{HABITS TO SAVE OUR HABITAT}

\section{0}

Cues for everyday actions are naturally disrupted when people move to a new place

or start a new job. ${ }^{62,63}$ By removing the familiar cues that activated old habits - such as the stores and streets of one's prior community-life changes can force people to make new decisions. In one personal sustainability intervention, U.K. households were provided with an in-person consultation, a bag of eco-friendly products, and brochures. ${ }^{62}$ Households that had moved in the prior three months were most influenced by the intervention, adopting changes such as using less water and walking or cycling for short trips. Presumably these recent movers had not yet had a chance to develop strong habits in their new residence, and their behavior was still malleable. The intervention had no effect, however, on long-term residents, whose habits were already in place. Thus, interventions might prove most effective when they target people after major life changes, when they are not yet hampered by cues for undesirable habits.

\section{Principle 3: Use Psychologically Informed Incentives \& Disincentives} Incentives and disincentives can be structured to effectively achieve environmental policy goals. Some policies, however, overlook evidence that such measures can be made more effective by drawing on key robust psychological principles. By designing incentives and disincentives to be immediate, salient, and tied to a specific behavior, policymakers can amplify the habit-forming potential of those interventions without increasing financial costs.

Disincentives are policies that impose actual or perceived costs on undesirable behavior. Research shows that increasing the salience of such costs increases their effectiveness. For instance, an intervention that increases the pain of paying - the aversive experience of letting go of one's money - can maximize the effect of a surcharge without increasing its monetary cost. ${ }^{64}$ The concrete, visceral experience of parting with cash is more aversive than the innocuous-seeming swipe of a credit card.

The pain of paying with cash affects what people purchase. Shoppers who used cash instead of a credit or debit card were less likely to make impulsive and unhealthy grocery store purchases, according to an analysis of the shopping trips of 1,000 U.S. households over a six-month period. ${ }^{65}$ These results imply that asking consumers to pay cash for less eco-friendly purchases and accepting credit cards or electronic payments for greener purchases - an approach that also leverages friction in environments where cash is rarely used - might make the cost of the less desirable option seem higher without an actual pricing change. 


\section{HABITS TO SAVE OUR HABITAT}

\section{1}

Even when using cash is impractical, payment can be made more painful by increasing its salience. In 1998, Singapore introduced Electronic Road Pricing, a tolling system that bills vehicles automatically as they pass through toll gates during peak traffic hours. When vehicles are charged through this system, an in-vehicle device (see Figure 2) emits a noticeable noise and displays a clearly visible decrease in the driver's remaining balance. This system has been widely successful at reducing congestion: A mere $\$ 1$ increase in tolls in 2013 increased public transit usage from $12 \%$ to $20 \%$ during morning commute hours. ${ }^{66}$ This example suggests that pairing a disincentive with a concrete, salient cue can influence even longentrenched habits.

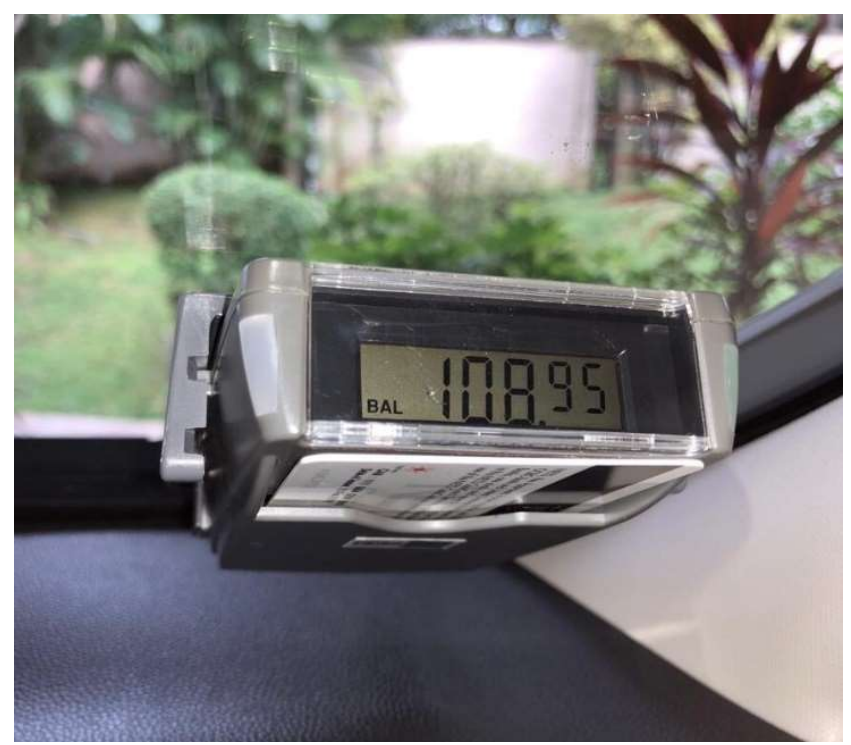

Figure 2. Electronic Road Pricing in-vehicle display unit

Note. Units like this one must be mounted on the dashboards of vehicles in Singapore. When a toll is charged, the unit's displayed balance decreases, and the unit emits an audible sound. The dashboard device makes payment convenient yet maintains the salience of being charged via immediate visual and auditory feedback.

Other cases demonstrate the importance of pairing incentives with salient feedback. For example, real-time feedback has been shown to induce sizable, lasting behavioral changes in household energy use that would have otherwise required much more costly incentives.

Economists have long argued for nonlinear energy-use pricing schemes - ones in which energy prices increase the more a household consumes or during times of peak energy use. However, behavior change in response to such pricing schemes has been minimal, ${ }^{67}$ a fact that makes sense from a psychological perspective: The 


\section{HABITS TO SAVE OUR HABITAT}

12

disincentive (a higher energy bill) usually arrives weeks after the action that caused it, and consumers do not know which specific actions caused the inflated bill. Although more than half of U.S. households have smart energy meters that could provide such actionable information, relatively few have in-home displays. ${ }^{68}$

One field trial in Connecticut compared the effects of a conventional nonlinear pricing scheme with an augmented treatment in which some households were provided with a smart in-home energy display. ${ }^{69}$ Households in the pricing-schemeonly condition did not reduce energy use, but households that received in-home displays reduced energy use by an impressive $11 \%$ to $14 \%$. A similar trial in Japan found a $16 \%$ reduction in energy use that persisted even at the three-month followup after the nonlinear pricing scheme was removed. ${ }^{70}$ Participants reported that they used appliances in more energy-efficient ways, suggesting that these households formed energy-saving habits rather than making one-time changes such as buying more efficient appliances.

Designers of disincentives can take advantage of another psychological insight: People value access to free products disproportionately more than they value access to products that are so cheap as to be virtually free. ${ }^{71}$ This means that small charges on undesirable behaviors can exert disproportionately strong effects.

Disincentivizing the use of single-use plastic bags by charging for them (usually a negligible amount) has reduced their use in countries from Botswana to Ireland. ${ }^{72,73}$ Notably, these disincentives have succeeded where heart-wrenching visuals depicting strangled marine life have failed. This provides another example of a structural, psychologically informed intervention succeeding where attitude-based ones have failed. The trivial size of the surcharge demonstrates again that effective incentives and disincentives need not be costly for governments or individuals.

Studies of parking provide further evidence of how small charges can have large effects. Parking spaces consume large quantities of funds and land, precluding other uses. The United States, for one, devotes more space to parking than to housing. ${ }^{74}$ Rescinding free parking is one of the strongest tools available for reducing car use. A review of workplace policies found that when employers stopped offering free parking as a benefit, the share of solo-driving commuters dropped by $41 \%{ }^{75}$ This effect held even for employers in Southern California, where most workers commute via single-occupancy vehicles. ${ }^{76}$

In some cases, financial incentives or disincentives need not be permanent, just kept in place long enough to establish new habits, especially if forming the habits involves relatively easy behavior changes. For example, a 10-week free pass to 


\section{HABITS TO SAVE OUR HABITAT}

\section{3}

travel on the Singapore subway prior to the crowded morning peak prompted a $6 \%$ increase in pre-peak commutes, relieving congestion that made transit less convenient and efficient. ${ }^{77}$ More important, the early morning commute became a habit for many riders that persisted after the intervention ended. A transit incentive tried in Copenhagen was less successful. ${ }^{78}$ In this trial, a free travel pass was offered for a shorter duration (four weeks) and required a major switch in transit modes (car to public transit). Commuting by public transit fell back to baseline levels after the Copenhagen promotion ended. As these cases exemplify, temporary incentives may be effective if they are repeated long enough to form habits and if the behavior change is relatively easy to accomplish.

\section{Habits Can Help Build Public Support Over Time}

Although the public is highly supportive of information-based policies to encourage pro-environment behaviors, attitudes about more effective behavioral interventions, such as nudges and incentives, are mixed. ${ }^{12}$ Effective interventions can achieve widespread acceptance, but this acceptance often materializes often only after repeated exposure. These policies thus must often be enacted before gaining public acceptance, and resistance to change may subside only after new behaviors become habits.

In Los Angeles, for example, people who do not ride the Metro report safety concerns as a chief reason for avoiding the rails. ${ }^{79}$ To address this, the Metro partnered with law enforcement in a crime-reduction effort that successfully decreased their already low onboard crime rates by $7 \% .{ }^{80}$ However, increased safety was not accompanied by increased ridership - annual Metro rides actually decreased by about 27 million rides (a 6\% reduction) between 2017 and 2019. ${ }^{81}$ Notably, habitual Metro riders routinely rate it as safer than do nonriders. ${ }^{79}$ Repeated Metro use apparently reduces riders' fears as they experience minimal crime and no longer perceive riding as unfamiliar and thus risky. ${ }^{82}$

Indeed, familiarity breeds liking. ${ }^{83}$ Simply practicing a behavior can increase people's liking and support for it. For example, reducing meat consumption is one of the most effective actions individuals can take to reduce their impact on the climate, but change in this domain is hampered by preferences for meat products over foods like fruits and vegetables. ${ }^{84}$ Instead of intervening to change people's attitudes toward sustainable foods, an alternative approach involves just providing regular opportunities for people to sample fruits and vegetables. ${ }^{85}$ Such repetition-based approaches can increase both liking and everyday consumption of these more ecofriendly choices, ${ }^{86}$ which in turn can reduce meat consumption. ${ }^{87}$ 


\section{HABITS TO SAVE OUR HABITAT}

\section{4}

Similarly, many pro-environment policies quickly gain acceptance once implemented. For instance, when Champaign, Illinois, instituted curbside recycling in 1987, public support for recycling increased markedly, and this upward trend continued over the next year. ${ }^{88}$ Acceptance of wind power turbines has followed a similar pattern: Although people may express initial doubts about turbines' effects, their opinions turn favorable over time. ${ }^{89}$

Even environmental policies that impose surcharges - one of the least-liked policy types $^{13}$ — can enjoy increased support once implemented. For example, after the 2015 enactment of a minimal 5-pence charge for single-use plastic bags in England, shoppers reported stronger support for the charge than before it was implemented. ${ }^{90}$ Furthermore, this shift had spillover effects, increasing support for charging for other types of plastic waste.

Congestion pricing, a policy designed to reduce traffic by charging drivers at peak driving periods, also attracts after-the-fact public support. Despite imposing a cost on individual drivers, congestion pricing schemes typically become popular once implemented. In Durham, England, support for congestion pricing rose from $49 \%$ at the time of implementation to $70 \%$ afterward. ${ }^{91}$ Similar congestion pricing policies in Europe saw upticks in acceptance once they were put in place. ${ }^{92}$ Such postimplementation shifts in attitudes might be driven by positive outcomes - in the case of congestion pricing, people come to appreciate reduced congestion, easier parking, and lower pollution levels ${ }^{93}$ - but they are also driven by acceptance of the status quo. ${ }^{92}$

Policymakers should not be deterred by mixed public support for some of the initiative types outlined in this article. Given the overall favorable public attitudes toward environmentally friendly policies, apparent resistance to specific interventions will likely dissipate over time as people come to support repeated actions, especially once their benefits become apparent. For instance, when the city of Pasadena, California, introduced parking meters, the meters generated \$1.2 million in revenue that helped revive the once-dilapidated city center. The visible improvements to the area helped shore up public support for this policy, despite Pasadena being a heavily car-dependent suburb. ${ }^{94}$ In short, rather than hoping to change behavior by first changing attitudes, public and private leaders can expect that attitude change will accompany behavior change when interventions are successful. 


\section{HABITS TO SAVE OUR HABITAT}

\section{5}

\section{Conclusion}

Public recognition of climate change has increased dramatically in the past two decades. However, people who believe it is important to reduce climate change do not always act accordingly. Actions by government and industry are key to bridging this gap. We hope this article will guide policymakers in enacting structural changes that empower the public to form habits that can mitigate climate change. The policy checklist included with this article (see the sidebar Checklist of Guiding Principles for Designing Effective Sustainability Interventions) may help by describing examples of specific psychological tools that policies can use for leveraging friction, cues, and incentives.

Many structural changes have the benefit of being cost-effective and straightforward to implement. For instance, merely setting thermostats to a lower default temperature in the winter can reduce energy use by increasing the friction of turning on heat. ${ }^{95}$ Action cues can be similarly easy to implement: Just painting footsteps leading toward recycling bins has been shown to reduce littering. ${ }^{96}$ Finally, psychologically informed incentives, such as a negligible surcharge on single-use plastics, can drive lasting behavior change while earning broad acceptance. ${ }^{72}$

Enduring behavior change requires structural change informed by lessons drawn from the psychology of habits. Achieving measurable progress in the fight against climate change is challenging, but the size of this task is dwarfed by its importance. Climate change is ultimately caused by physical and social structures that foster unsustainable habits. The solution must similarly come from reimagining those structures and creating new ones that instead foster sustainability.

\section{Author affiliation}

Mazar: University of Southern California. Tomaino and Carmon: INSEAD. Wood: University of Southern California and INSEAD. Corresponding author's e-mail: amazar@usc.edu.

\section{Checklist of Guiding Principles for Designing Effective Sustainability Interventions}

Reduce (or increase) friction for (un)sustainable behaviors

$\checkmark$ Minimize (or maximize) delay

$\checkmark$ Eliminate (or add) steps

$\checkmark$ Reduce (or increase) thinking required

$\square$ Leverage action cues

$\checkmark$ Make cues salient

$\checkmark$ Suggest simple, concrete actions 


\section{HABITS TO SAVE OUR HABITAT}

16

$$
\checkmark \text { Place cues close to actions }
$$

\section{Leverage psychologically informed incentives}

$\checkmark$ Set up immediate feedback

$\checkmark$ Tie feedback to specific actions

$\checkmark$ Maximize psychological pain of disincentives

\section{References}

1. Grist. (2016, May 20). An oral history of An inconvenient truth. https://grist.org/feature/aninconvenient-truth-oral-history/

2. IMDb. (n.d.). Documentary (sorted by US box office descending). Retrieved January 26, 2021, from

https://www.imdb.com/search/title/?title_type=documentary\&sort=boxoffice_gross_us,d esc

3. Norwegian Nobel Committee. (2007). The Nobel Peace Prize for 2007. The Nobel Prize Organization. https:/www.nobelprize.org/prizes/peace/2007/press-release/

4. Nielsen \& Environmental Change Institute. (2007). Climate change \& influential spokespeople: A global Nielsen online survey. University of Oxford. https://www.eci.ox.ac.uk/publications/downloads/070709nielsen-celeb-report.pdf

5. Nolan, J. M. (2010). “An inconvenient truth” increases knowledge, concern, and willingness to reduce greenhouse gases. Environment and Behavior, 42(5), 643-658. https://doi.org/10.1177/0013916509357696

6. Poushter, J., \& Huang, C. (2019, February 10). Climate change still seen as top global threat, but cyberattacks a rising concern. Pew Research Center. https://www.pewresearch.org/global/2019/02/10/climate-change-still-seen-as-the-topglobal-threat-but-cyberattacks-a-rising-concern/

7. Hornsey, M. J., Harris, E. A., Bain, P. G., \& Fielding, K. S. (2016). Meta-analyses of the determinants and outcomes of belief in climate change. Nature Climate Change, 6(6), 622-626. https://doi.org/10.1038/nclimate2943

8. Jacobsen, G. D. (2011). The Al Gore effect: An inconvenient truth and voluntary carbon offsets. Journal of Environmental Economics and Management, 61(1), 67-78. https://doi.org/10.1016/j.jeem.2010.08.002 


\section{HABITS TO SAVE OUR HABITAT}

17

9. Hale, T. (2018). Catalytic cooperation (Blavatnik School of Government Working Paper 2018/026). University of Oxford. https://www.bsg.ox.ac.uk/sites/default/files/201809/BSG-WP-2018-026.pdf

10. U.S. Government Accountability Office. (2017). Public relations spending: Selected agencies' activities supported by contracts and public affairs staff (Report GAO-17-711). https://www.gao.gov/assets/690/687089.pdf

11. Abrahamse, W., Steg, L., Vlek, C., \& Rothengatter, T. (2005). A review of intervention studies aimed at household energy conservation. Journal of Environmental Psychology, 25(3), 273-291. https://doi.org/10.1016/j.jenvp.2005.08.002

12. Marteau, T. M. (2017). Towards environmentally sustainable human behaviour: Targeting non-conscious and conscious processes for effective and acceptable policies.

Philosophical Transactions of the Royal Society A: Mathematical, Physical and Engineering Sciences, 375(2095), Article 20160371. https://doi.org/10.1098/rsta.2016.0371

13. Reisch, L. A., \& Sunstein, C. R. (2016). Do Europeans like nudges? Judgment and Decision Making, 11(4), 310-325.

14. Mazar, A., \& Wood, W. (2018). Defining habit in psychology. In B. Verplanken (Ed.), The psychology of habit: Theory, mechanisms, change, and contexts (pp. 13-29). Springer International Publishing. https://doi.org/10.1007/978-3-319-97529-0_2

15. Brijs, K., Daniels, S., Brijs, T., \& Wets, G. (2011). An experimental approach towards the evaluation of a seat belt campaign with an inside view on the psychology behind seat belt use. Transportation Research Part F: Traffic Psychology and Behaviour, 14(6), 600-613. https://doi.org/10.1016/j.trf.2011.07.003

16. Lacroix, K. (2018). Comparing the relative mitigation potential of individual proenvironmental behaviors. Journal of Cleaner Production, 195, 1398-1407. https://doi.org/10.1016/j.jclepro.2018.05.068

17. Cohen, D., \& Farley, T. A. (2007). Eating as an automatic behavior. Preventing Chronic Disease, 5(1), Article A23. https:/www.ncbi.nlm.nih.gov/pmc/articles/PMC2248777/

18. Chen, C.-F., \& Chao, W.-H. (2011). Habitual or reasoned? Using the theory of planned behavior, technology acceptance model, and habit to examine switching intentions toward public transit. Transportation Research Part F: Traffic Psychology and 


\section{HABITS TO SAVE OUR HABITAT}

18

Behaviour, 14(2), 128-137. https://doi.org/10.1016/j.trf.2010.11.006

19. Hanson, S., \& Huff, J. O. (1988). Systematic variability in repetitious travel. Transportation, 15(1-2), 111-135.

20. Pierce, J., Schiano, D. J., \& Paulos, E. (2010). Home, habits, and energy: Examining domestic interactions and energy consumption. In CHI '10: Proceedings of the SIGCHI Conference on Human Factors in Computing Systems (pp. 1985-1994). https://doi.org/10.1145/1753326.1753627

21. Neal, D. T., Wood, W., \& Drolet, A. (2013). How do people adhere to goals when willpower is low? The profits (and pitfalls) of strong habits. Journal of Personality and Social Psychology, 104(6), 959-975. https://doi.org/10.1037/a0032626

22. Schwabe, L., \& Wolf, O. T. (2009). Stress prompts habit behavior in humans. Journal of Neuroscience, 29(22), 7191-7198. https://doi.org/10.1523/JNEUROSCI.0979-09.2009

23. Itzchakov, G., Uziel, L., \& Wood, W. (2018). When attitudes and habits don't correspond: Self-control depletion increases persuasion but not behavior. Journal of Experimental Social Psychology, 75, 1-10. https://doi.org/10.1016/j.jesp.2017.10.011

24. Klöckner, C. A., \& Matthies, E. (2004). How habits interfere with norm-directed behaviour: A normative decision-making model for travel mode choice. Journal of Environmental Psychology, 24(3), 319-327. https://doi.org/10.1016/j.jenvp.2004.08.004

25. Allcott, H., \& Rogers, T. (2014). The short-run and long-run effects of behavioral interventions: Experimental evidence from energy conservation. American Economic Review, 104(10), 3003-3037. https://doi.org/10.1257/aer.104.10.3003

26. Webb, T. L., Sheeran, P., \& Luszczynska, A. (2009). Planning to break unwanted habits: Habit strength moderates implementation intention effects on behaviour change. British Journal of Social Psychology, 48(3), 507-523. https://doi.org/10.1348/014466608X370591

27. Wyer, J. F. (2018). Urban transportation mode choice and trip complexity: Bicyclists stick to their gears. Economic Inquiry, 56(3), 1777-1787. https://doi.org/10.1111/ecin.12524

28. Aarts, H., Verplanken, B., \& van Knippenberg, A. (1997). Habit and information use in travel mode choices. Acta Psychologica, 96(1-2), 1-14. https://doi.org/10.1016/S0001$\underline{6918(97) 00008-5}$

29. Verplanken, B., Aarts, H., \& Knippenberg, A. V. (1997). Habit, information acquisition, and 


\section{HABITS TO SAVE OUR HABITAT}

19

the process of making travel mode choices. European Journal of Social Psychology, 27(5), 539-560. https://doi.org/10.1002/(SICI)1099-0992(199709/10)27:5<539::AIDEJSP831>3.0.CO;2-A

30. Hansen, P. G., Schilling, M., \& Malthesen, M. S. (2019). Nudging healthy and sustainable food choices: Three randomized controlled field experiments using a vegetarian lunchdefault as a normative signal. Journal of Public Health. Advance online publication. https://doi.org/10.1093/pubmed/fdz154

31. Kurz, V. (2018). Nudging to reduce meat consumption: Immediate and persistent effects of an intervention at a university restaurant. Journal of Environmental Economics and Management, 90, 317-341. https://doi.org/10.1016/j.jeem.2018.06.005

32. DefaultVeg. (n.d.). DefaultVeg x Institutions. Retrieved March 25, 2021, from https://defaultveg.org/\#!/institutions

33. Avni-Babad, D. (2011). Routine and feelings of safety, confidence, and well-being. British Journal of Psychology, 102(2), 223-244. https://doi.org/10.1348/000712610X513617

34.White, K., Hardisty, D. J., \& Habib, R. (2019). The elusive green consumer. Harvard Business Review, 97(4), 124-133.

35. Austin, J., Hatfield, D. B., Grindle, A. C., \& Bailey, J. S. (1993). Increasing recycling in office environments: The effects of specific, informative cues. Journal of Applied Behavior Analysis, 26(2), 247-253. https://doi.org/10.1901/jaba.1993.26-247

36. Holland, R. W., Aarts, H., \& Langendam, D. (2006). Breaking and creating habits on the working floor: A field-experiment on the power of implementation intentions. Journal of Experimental Social Psychology, 42(6), 776-783.

https://doi.org/10.1016/j.jesp.2005.11.006

37. Ludwig, T., Gray, T. W., \& Rowell, A. (1998). Increasing recycling in academic buildings: A systematic replication. Journal of Applied Behavior Analysis, 31(4), 683-686. https://doi.org/10.1901/jaba.1998.31-683

38. Ben-Elia, E., \& Avineri, E. (2015). Response to travel information: A behavioural review. Transport Reviews, 35(3), 352-377. https://doi.org/10.1080/01441647.2015.1015471

39. Brakewood, C., \& Watkins, K. (2019). A literature review of the passenger benefits of realtime transit information. Transport Reviews, 39(3), 327-356. https://doi.org/10.1080/01441647.2018.1472147 


\section{HABITS TO SAVE OUR HABITAT}

20

40. Kaushal, N., \& Rhodes, R. E. (2015). Exercise habit formation in new gym members: A longitudinal study. Journal of Behavioral Medicine, 38(4), 652-663. https://doi.org/10.1007/s10865-015-9640-7

41. Lally, P., van Jaarsveld, C. H. M., Potts, H. W. W., \& Wardle, J. (2010). How are habits formed: Modelling habit formation in the real world. European Journal of Social Psychology, 40(6), 998-1009. https://doi.org/10.1002/ejsp.674

42. Astroza, S., Garikapati, V. M., Bhat, C. R., Pendyala, R. M., Lavieri, P. S., \& Dias, F. F. (2017). Analysis of the impact of technology use on multimodality and activity travel characteristics. Transportation Research Record, 2666(1), 19-28. https://doi.org/10.3141/2666-03

43. Tomaino, G., Teow, J., Carmon, Z., Lee, L., Ben-Akiva, M., Chen, C., Leong, W. Y., Li, S., Yang, N., \& Zhao, J. (2020). Mobility as a service (MaaS): The importance of transportation psychology. Marketing Letters, 31(4), 419-428. https://doi.org/10.1007/s11002-020-09533-9

44. Buehler, R., Pucher, J., \& Kunert, U. (2009). Making transportation sustainable: Insights from Germany. Brookings Institution, Metropolitan Policy Program. https://www.brookings.edu/wpcontent/uploads/2016/06/0416 germany transportation_report.pdf

45. Le, H. T. K., Buehler, R., \& Hankey, S. (2019). Have walking and bicycling increased in the US? A 13-year longitudinal analysis of traffic counts from 13 metropolitan areas.

Transportation Research Part D: Transport and Environment, 69, 329-345. https://doi.org/10.1016/j.trd.2019.02.006

46 Boulange, C., Gunn, L., Giles-Corti, B., Mavoa, S., Pettit, C., \& Badland, H. (2017).

Examining associations between urban design attributes and transport mode choice for walking, cycling, public transport and private motor vehicle trips. Journal of Transport \& Health, 6, 155-166. https://doi.org/10.1016/j.jth.2017.07.007

47. Kullgren, I. K. (2011, March 19). Portland Mayor Sam Adams says Portland's spent on its bike infrastructure what it would normally spend on a single mile of highway. Polifact. https://www.politifact.com/factchecks/2011/mar/19/sam-adams/portland-mayor-samadams-says-portlands-spent-its-/

48. Schwanen, T., \& Mokhtarian, P. L. (2005). What if you live in the wrong neighborhood? The 


\section{HABITS TO SAVE OUR HABITAT}

impact of residential neighborhood type dissonance on distance traveled. Transportation Research Part D: Transport and Environment, 10(2), 127-151. https://doi.org/10.1016/j.trd.2004.11.002

49. Houten, R. V., Nau, P. A., \& Merrigan, M. (1981). Reducing elevator energy use: A comparison of posted feedback and reduced elevator convenience. Journal of Applied Behavior Analysis, 14(4), 377-387. https://doi.org/10.1901/jaba.1981.14-377

50. Ebeling, F., \& Lotz, S. (2015). Domestic uptake of green energy promoted by opt-out tariffs. Nature Climate Change, 5(9), 868-871. https://doi.org/10.1038/nclimate2681

51. Loock, C.-M., Staake, T., \& Thiesse, F. (2013). Motivating energy-efficient behavior with green IS: An investigation of goal setting and the role of defaults. MIS Quarterly, 37(4), 1313-1332. https://doi.org/10.25300/MISQ/2013/37.4.15

52. Heydarian, A., Pantazis, E., Carneiro, J. P., Gerber, D., \& Becerik-Gerber, B. (2016). Lights, building, action: Impact of default lighting settings on occupant behaviour. Journal of Environmental Psychology, 48, 212-223. https://doi.org/10.1016/i.jenvp.2016.11.001

53. Thiagarajah, K., \& Getty, V. M. (2013). Impact on plate waste of switching from a tray to a trayless delivery system in a university dining hall and employee response to the switch. Journal of the Academy of Nutrition and Dietetics, 113(1), 141-145. https://doi.org/10.1016/j.jand.2012.07.004

54. Arvai, J. (2012, April 3). Thinking fast and thinking slow: How our minds make us behave sustainably. The Guardian. https://www.theguardian.com/sustainable-business/thinking$\underline{\text { sustainable-choices-mind-decisions }}$

55. Ewing, R. (2001). Impacts of traffic calming. Transportation Quarterly, 55(1), 33-46.

56. Wood, W., \& Rünger, D. (2016). Psychology of habit. Annual Review of Psychology, 67(1), 289-314. https://doi.org/10.1146/annurev-psych-122414-033417

57. Wu, D. W.-L., Lenkic, P. J., DiGiacomo, A., Cech, P., Zhao, J., \& Kingstone, A. (2018). How does the design of waste disposal signage influence waste disposal behavior? Journal of Environmental Psychology, 58, 77-85. https://doi.org/10.1016/j.jenvp.2018.07.009

58. Werner, C. M., Rhodes, M. U., \& Partain, K. K. (1998). Designing effective instructional signs with schema theory: Case studies of polystyrene recycling. Environment and Behavior, 30(5), 709-735. https://doi.org/10.1177/001391659803000506 


\section{HABITS TO SAVE OUR HABITAT}

22

59. Cialdini, R. B., Reno, R. R., \& Kallgren, C. A. (1990). A focus theory of normative conduct: Recycling the concept of norms to reduce littering in public places. Journal of Personality and Social Psychology, 58(6), 1015-1026. https://doi.org/10.1037/0022$\underline{3514.58 .6 .1015}$

60. Khashe, S., Heydarian, A., Gerber, D., Becerik-Gerber, B., Hayes, T., \& Wood, W. (2015). Influence of LEED branding on building occupants' pro-environmental behavior. Building and Environment, 94(Part 2), 477-488. https://doi.org/10.1016/j.buildenv.2015.10.005

61. PepsiCo Recycling, Keep America Beautiful, CBRE, \& Action Research. (2015). Recycling at work: Research to inform improved recycling in the workplace. Keep America Beautiful. https://kab.org/wpcontent/uploads/2019/08/RecyclingatWork_Research_Report_2015.pdf

62. Verplanken, B., Walker, I., Davis, A., \& Jurasek, M. (2008). Context change and travel mode choice: Combining the habit discontinuity and self-activation hypotheses. Journal of Environmental Psychology, 28(2), 121-127. https://doi.org/10.1016/j.jenvp.2007.10.005

63. Wood, W., Tam, L., \& Witt, M. G. (2005). Changing circumstances, disrupting habits. Journal of Personality and Social Psychology, 88(6), 918-933. https://doi.org/10.1037/0022-3514.88.6.918

64. Prelec, D., \& Loewenstein, G. (1998). The red and the black: Mental accounting of savings and debt. Marketing Science, 17(1), 4-28. https://doi.org/10.1287/mksc.17.1.4

65. Thomas, M., Desai, K. K., \& Seenivasan, S. (2011). How credit card payments increase unhealthy food purchases: Visceral regulation of vices. Journal of Consumer Research, 38(1), 126-139. https://doi.org/10.1086/657331

66. Agarwal, S., \& Koo, K. M. (2016). Impact of electronic road pricing (ERP) changes on transport modal choice. Regional Science and Urban Economics, 60, 1-11. https://doi.org/10.1016/j.regsciurbeco.2016.05.003

67. Ito, K. (2014). Do consumers respond to marginal or average price? Evidence from nonlinear electricity pricing. American Economic Review, 104(2), 537-563. https://doi.org/10.1257/aer.104.2.537

68. Mooney, C. (2015, January 9). Americans are this close to finally understanding their electricity bills. Washington Post. https:/www.washingtonpost.com/news/energy- 


\section{HABITS TO SAVE OUR HABITAT}

23

environment/wp/2015/01/29/americans-are-this-close-to-finally-understanding-theirelectricity-bills/

69. Jessoe, K., \& Rapson, D. (2014). Knowledge is (less) power: Experimental evidence from residential energy use. American Economic Review, 104(4), 1417-1438. https://doi.org/10.1257/aer.104.4.1417

70. Ito, K., Ida, T., \& Tanaka, M. (2018). Moral suasion and economic incentives: Field experimental evidence from energy demand. American Economic Journal: Economic Policy, 10(1), 240-267. https://doi.org/10.1257/pol.20160093

71. Shampanier, K., Mazar, N., \& Ariely, D. (2007). Zero as a special price: The true value of free products. Marketing Science, 26(6), 742-757. https://doi.org/10.1287/mksc.1060.0254

72. Convery, F., McDonnell, S., \& Ferreira, S. (2007). The most popular tax in Europe? Lessons from the Irish plastic bags levy. Environmental and Resource Economics, 38(1), 1-11. https://doi.org/10.1007/s10640-006-9059-2

73. Dikgang, J., \& Visser, M. (2012). Behavioural response to plastic bag legislation in Botswana. South African Journal of Economics, 80(1), 123-133. https://doi.org/10.1111/j.1813-6982.2011.01289.x

74. Shoup, D. (2014). The high cost of minimum parking requirements. In S. Ison \& C. Mulley (Eds.), Transport and sustainability (Vol. 5, pp. 87-113). Emerald Group Publishing. https://doi.org/10.1108/S2044-994120140000005011

75. Willson, R. W., \& Shoup, D. C. (1990). Parking subsidies and travel choices: Assessing the evidence. Transportation, 17(2), 141-157. https://doi.org/10.1007/BF02125333

76. California Center for Jobs and the Economy. (2016). California commuters continue to choose single occupant vehicles. https://centerforjobs.org/ca/special-reports/californiacommuters-continue-to-choose-single-occupant-vehicles

77. Yang, N., \& Lim, Y. L. (2018). Temporary incentives change daily routines: Evidence from a field experiment on Singapore's subways. Management Science, 64(7), 3365-3379. https://doi.org/10.1287/mnsc.2017.2731

78. Thøgersen, J., \& Møller, B. (2008). Breaking car use habits: The effectiveness of a free onemonth travelcard. Transportation, 35(3), 329-345. https://doi.org/10.1007/s11116-0089160-1 


\section{HABITS TO SAVE OUR HABITAT}

24

79. Center for Economic and Social Research. (2020). LA barometer: The mobility report. University of Southern California. https://cesr.usc.edu/sites/default/files/Mobility_Wave1_Report final.pdf

80. Metro. (2018). Metro system security \& law enforcement 2018 report: Enhancing safety, building trust. https://media.metro.net/riding/images/System Security and Law Enforcement FY18 r eport.pdf

81. Metro. (2020). Interactive estimated ridership stats. http://isotp.metro.net/MetroRidership/YearOverYear.aspx

82. Keage, H. A. D., \& Loetscher, T. (2018). Estimating everyday risk: Subjective judgments are related to objective risk, mapping of numerical magnitudes and previous experience. PLoS ONE, 13(12), Article e0207356. https://doi.org/10.1371/journal.pone.0207356

83. Reber, R., Schwarz, N., \& Winkielman, P. (2004). Processing fluency and aesthetic pleasure: Is beauty in the perceiver's processing experience? Personality and Social Psychology Review, 8(4), 364-382. https://doi.org/10.1207/s15327957pspr0804 3

84. Barclay, E., \& Aubrey, A. (2016, February 26). Eat less meat, we're told. But Americans' habits are slow to change. NPR. https://www.npr.org/sections/thesalt/2016/02/26/465431695/eat-less-meat-were-told-butamericans-habits-are-slow-to-change

85. Appleton, K. M. (2012). Repeated exposure to fruit results in increased fruit intakes in older low consumers of fruit [Abstract]. Appetite, 59(2), 620. https://doi.org/10.1016/j.appet.2012.05.040

86. Appleton, K. M., Hemingway, A., Rajska, J., \& Hartwell, H. (2018). Repeated exposure and conditioning strategies for increasing vegetable liking and intake: Systematic review and meta-analyses of the published literature. The American Journal of Clinical Nutrition, 108(4), 842-856. https://doi.org/10.1093/ajcn/nqy143

87. Garnett, E. E., Balmford, A., Sandbrook, C., Pilling, M. A., \& Marteau, T. M. (2019). Impact of increasing vegetarian availability on meal selection and sales in cafeterias. Proceedings of the National Academy of Sciences, USA, 116(42), 20923-20929. https://doi.org/10.1073/pnas.1907207116

88. Vining, J., \& Ebreo, A. (1992). Predicting recycling behavior from global and specific 
HABITS TO SAVE OUR HABITAT

25

environmental attitudes and changes in recycling opportunities. Journal of Applied Social Psychology, 22(20), 1580-1607. https://doi.org/10.1111/j.1559-1816.1992.tb01758.x

89. Wolsink, M. (2007). Wind power implementation: The nature of public attitudes: Equity and fairness instead of 'backyard motives.' Renewable and Sustainable Energy Reviews, 11(6), 1188-1207. https://doi.org/10.1016/j.rser.2005.10.005

90. Thomas, G. O., Sautkina, E., Poortinga, W., Wolstenholme, E., \& Whitmarsh, L. (2019). The English plastic bag charge changed behavior and increased support for other charges to reduce plastic waste. Frontiers in Psychology, 10, Article 266. https://doi.org/10.3389/fpsyg.2019.00266

91. Santos, G. (2004). Urban road pricing in the U.K. Research in Transportation Economics, 9, 251-282. https://doi.org/10.1016/S0739-8859(04)09011-0

92. Hess, S., \& Börjesson, M. (2019). Understanding attitudes towards congestion pricing: A latent variable investigation with data from four cities. Transportation Letters, 11(2), $63-$ 77. https://doi.org/10.1080/19427867.2016.1271762

93. Schuitema, G., Steg, L., \& Forward, S. (2010). Explaining differences in acceptability before and acceptance after the implementation of a congestion charge in Stockholm.

Transportation Research Part A: Policy and Practice, 44(2), 99-109. https://doi.org/10.1016/j.tra.2009.11.005

94. Shoup, D. (2020). Learning from parking reforms in other cities. In D. Pojani, J. Corcoran, N. Sipe, I. Mateo-Babiano, \& D. Stead (Eds.), Parking: An international perspective (pp. 1-14). Elsevier. https://doi.org/10.1016/B978-0-12-815265-2.00001-7

95. Brown, Z., Johnstone, N., Haščič, I., Vong, L., \& Barascud, F. (2013). Testing the effect of defaults on the thermostat settings of OECD employees. Energy Economics, 39, 128 134. https://doi.org/10.1016/j.eneco.2013.04.011

96. Keep Britain Tidy. (2015). Case study: Green footprints. Centre for Social Innovation. https://www.keepbritaintidy.org/sites/default/files/resources/KBT_CFSI_Green_Footprin ts_Case_Study_2015.pdf 
HABITS TO SAVE OUR HABITAT

26 
Table 1. Core principles for designing sustainable policies, examples, \& potential implementers

\begin{tabular}{|c|c|c|c|c|}
\hline Principle & Tactic & Desired behavior & Example & Who should implement? \\
\hline \multirow[t]{5}{*}{ Modify friction } & $\begin{array}{l}\text { Reduce friction } \\
\text { on desirable } \\
\text { behavior }\end{array}$ & Waste recycling & $\begin{array}{l}\text { Place recycling bins in accessible locations, next to } \\
\text { conventional trash cans }\end{array}$ & $\begin{array}{l}\text { Government officials at the local and } \\
\text { national levels; school administrators; } \\
\text { business leaders and business regulation } \\
\text { agencies }\end{array}$ \\
\hline & & Public transit use & $\begin{array}{l}\text { Integrate apps and ticket services for a seamless } \\
\text { public transit experience }\end{array}$ & $\begin{array}{l}\text { Government officials at the local and } \\
\text { national levels; business leaders and } \\
\text { business regulation agencies }\end{array}$ \\
\hline & $\begin{array}{l}\text { Increase friction } \\
\text { on undesirable } \\
\text { behavior }\end{array}$ & $\begin{array}{l}\text { Reduced meat } \\
\text { consumption }\end{array}$ & Make default menu choices vegetarian & School administrators; restaurants \\
\hline & & $\begin{array}{l}\text { Reduced single- } \\
\text { occupancy vehicle use }\end{array}$ & $\begin{array}{l}\text { Use traffic-free zones and speed limits to make } \\
\text { driving more effortful }\end{array}$ & $\begin{array}{l}\text { Government officials, particularly at the } \\
\text { local level }\end{array}$ \\
\hline & & $\begin{array}{l}\text { Reduced energy } \\
\text { consumption }\end{array}$ & $\begin{array}{l}\text { Set low winter and high summer thermostat } \\
\text { temperature defaults }\end{array}$ & Business leaders \\
\hline \multirow[t]{3}{*}{$\begin{array}{l}\text { Leverage action } \\
\text { cues }\end{array}$} & $\begin{array}{l}\text { Provide actions } \\
\text { cues }\end{array}$ & Waste recycling & $\begin{array}{l}\text { Provide large desk-side recycling bins and small } \\
\text { trash bins }\end{array}$ & $\begin{array}{l}\text { Government officials at the local and } \\
\text { national levels; business leaders }\end{array}$ \\
\hline & & & $\begin{array}{l}\text { Provide simple visual signage on dining hall trash } \\
\text { cans }\end{array}$ & School administrators \\
\hline & Disrupt old cues & $\begin{array}{l}\text { Eco-friendly behavior in } \\
\text { new environments }\end{array}$ & $\begin{array}{l}\text { Focus environmental interventions on people } \\
\text { who moved recently }\end{array}$ & $\begin{array}{l}\text { Government officials; nongovernmental } \\
\text { organizations }\end{array}$ \\
\hline
\end{tabular}




Use
psychologically
informed
incentives and
disincentives

disincentives

\section{Design incentives Encourage pro-}

and disincentives environmental

to be immediate,

salient, and tied to

a specific action purchasing

Reduce traffic

congestion

Reduce household

energy use
Impose minor charges on single-use plastics;

require cash for less-green purchases

Provide real-time in-vehicle auditory and visual displays of congestion charges

Provide in-home smart energy meter displays showing real-time costs
Government officials, particularly at the national level

Government officials at the local and national levels

Government officials at the local and national levels; business leaders and business regulation agencies 